\title{
BRAND ORIENTATION OF SMALL ENTERPRISES: A STUDY BASED ON APPARELS INDUSTRY IN KHULNA CITY
}

\author{
Fatima Khan ${ }^{1}$, Khan Abdullah Adnan ${ }^{2}$ \\ ${ }^{1}$ Lecturer in Finance, Department of Business Administration, Northern University \\ Bangladesh \\ ${ }^{2}$ Independent Researcher, BBA Student Khulna University
}

\begin{abstract}
This paper studies the brand orientation-business performance association in the context of micro enterprises. Given the apparent need for investigation on branding in small enterprises, the goal of this study is to inspect how brand orientation rears to the performance of small enterprises carrying out in diverse situations. The paper builds on the contingency theory, according to which a business strategy is likely to produce different consequences in different contexts. It also scan how brand orientation relates to other branding and marketing theories, including brand identity and alternative approaches such as market orientation. A qualitative research approach is adopted. Besides contributing to the assumption of small enterprises branding by empirical studying the argument that branding is vital also for small enterprises and not just for big firms, this paper provides practitioners with much required information about whether and when brand orientation gives value to their business performance.
\end{abstract}

\section{KEYWORDS}

Brand Orientation, Consumer Orientation, Competitor Orientation, Inter-Functional Co-ordination, Brand Performance

\section{INTRODUCTION}

Whereas the world of branding is clearly subjugated by big businesses: what is less assured is how small and medium enterprises fit into this world? Specified that entrepreneurs were hindered by often-strained assets. They questioned whether affirmative brand equity added to a small and medium enterprises (small enterprises) ability to grow? Branding in small enterprises has been tagged as a rarely studied fact. This study satisfies this research gap by adding to our understanding of branding within small enterprises. Branding and brand orientation has attracted noteworthy interest since the early 1990s (Aman 2015). Several clarifications have been suggested ranging from where brand individuality and consumer interaction were stated to carry a competitive advantage, to who concerted on a logical approach and the release of a constant, consistent and applicable offer made to the buyer.

Increasing our understanding of the practice of branding in small enterprises is vital as brand orientation augments the sustainable value of both the company and its products and services (Ahonen and Moore 2005). This study fills a infringe in the literature in reentering and bringing 
up to date earlier conceptual research. Categorized brand orientation as a determinant of a firm's competitive perimeter and its long-term survival. The impending importance of brand orientation has been well-documented in the literature through theoretical development and through several case studies. These studies concur in their contention that: brand orientation can enhance a small enterprise's performance. Some studies suggest that branding is sometimes seen as an oxymoron; other concerns are suggested that within small enterprises, brand-orientation ability is perpetually incarnate by vague positioning and indistinctiveness. These somewhat down-beat viewpoint suggest a number of inferences for small enterprises and for the managing their brands (Abimbola, Vallaster et al. 2007). A contemporary study was proposed to address the deficiency of existing literatures composed around and on small enterprise brands and branding policies. Again some empirical researches have been composed on the co-ordination of brand orientation and the successful brand management (O'Callaghan 2009). One essential element of a brand management system is proposed by as interface: a appreciably important route in customer relationship managing. At the same time as demeanor a previous study, found that: no informant refer to their product or service as a brand; or mentioned their customers' views on brands. A need to explore deeper into the nature of small enterprises and branding was therefore suggested during these encounters. This study was sought after to construct upon earlier research to compile pragmatic findings and to recommend a small enterprise brand orientation model. In spite of several studies produced between 2005 and 2009, a scarcity of more recent small enterprise branding studies predominates (Abimbola 2001). This paper therefore, aims to enhance existing small enterprise brand research; at a regional level. This is an exploratory research in nature and was produced in collaboration with small enterprise practitioners; who openhandedly reported their personal experiences of branding expansion and their customers, who equally liberally cited their experiences of the small enterprises they patronized.

For competing in the domestic as well as the global market, it is very important to create, and sustain a strong brand icon is necessary. Some apparel makers effort to create a brand for their product in the global market, where as many others just provide to international buying houses or retail chains according to their required specifications. Branded apparels not only add a fashionable image to the clothing, but it also gives something additional to the consumers. It enables them to make perceptions about the value of the apparel and the brand itself. The 'brand equity' is the margin of cash the customer pays for a non-branded garment, and a branded one. The client can buy a similar clothes somewhere else; without the label and for a lesser price as well. But, a branded apparel with a label on it gives a status symbol to the consumer thus satisfying his personality. The status that the brand image carries helps in endorsing the product among status savvy customers. Bangladesh manufactures ready-made garment that are divided mainly into two broad categories: woven and knit products. Shirts, T-shirts and trousers are the key woven products and undergarments, socks, stockings, T-shirts, sweaters and other casual and soft garments are the major knit products. Woven garment products dominate the garment export earnings of the country since the early 1990s; such products currently account for more than 40 per cent of the country's total RMG export earnings (BGMEA website). Though various types of garments are manufactured in the country, only a little categories, such as T-shirts, shirts, trousers, sweaters and jackets, constitute the major production-share. Economies of scale for large-scale production and export-quota affluences in the corresponding categories are the chief reasons for such a thin product concentration. There are about $\$ 15$ billion in exports in the year 2010, ready-made garments are the country's most important industrial sector; they stand for $13 \%$ of GDP and more than $75 \%$ of total exports. New surveys carried out by the consulting firm McKinsey and the accounting firm KPMG identified lucratively cheap prices as the most important reason for purchasing from Bangladesh. Price levels will stay highly competitive in the 
future, since important efficiency increases will counteract rising wage costs. Other than labor cost and duty benefit; raw materials and factory settlement costs are also cheaper in Bangladesh comparing to other countries. Bangladesh is also getting benefit from various preferential trade agreements given that tax free entry into several dozen countries. But Bangladesh has its own drawbacks to overcome, such as impediment to investment include untrustworthy power supply, high interest rates, corruption, and weaknesses in law and order.

\section{LITERATURE REVIEW}

The significance of brand building has been recognized among both academic and practitioners researchers. Particularly in the business branding literature it has been evidently affirmed that brands should be considered as part of organizational core values and processes in order for them to be secured in the entire organization (Urde 1999; Simões and Dibb 2001; Balmer and Gray 2003). According to the study of Wong and Merrilees (2007), the approaches towards brand building and brand's role in business is crucial in whether or not the brand is utilized within the institute. Urde (1999) described brand orientation as "an approach in which the procedures of the business turn around the creation, development and protection of brand identity in an continuing interaction with the target market with the plan of achieving lasting spirited advantages in the shape of brands". Merrilees (2005) claimed that brand orientation refers to the "extent to which the brand becomes a vital and coordinating factor or core of a marketing policy". Brand orientation places the base for all the marketing activities and, so it should be considered into account in the strategic marketing planning of a company. Wong and Merrilees (2008) argued that brand may be seen as a way to attain aggressive advantage and that it becomes a planned benefit for the company in the long run. They added that brand orientation should be seen as a prerequisite for corporations that look for brand-centered performance. While brand orientation demonstrates firm's inner proclivity to build and develop a brand, brand performance counts the achievement of the brand in the market. According to the previous marketing literatures, brand performance is over and over again discussed together with the idea of brand equity. Aaker (1991) showed that brand equity is composed of brand name awareness, loyal customers, perceived quality and brand associations that insert (or deduct) value to the product or service. A number of empirical studies have been conducted testing the determinants of Aaker's brand equity model in different industries. In recent studies measures of brand equity have been adapted to assess also brand performance (Chaudhuri and Holbrook 2001; Wong and Merrilees 2007; Wong and Merrilees 2008).

Brand orientation is a thoroughly identity-driven approach that observes brands as a center for an organization or an organizational wing, and its strategy. In the same way, market orientation is an image-driven approach. Primarily, brand orientation and market orientation come out to be two singular strategic options. "Brand orientation is when an organization chooses brand management as a strategic and comprehensive activity of the entire organization and views themselves as a brand or brands" (Aaker, 2000a). Therefore, this definition can be presumed to mean that the organization organizes itself around brand management and chooses to exercise it as a discipline. (Gromark \& Melin, 2011). Urde (1999) defines brand orientation as a way to revolve around the creation, development and protection of brand identity in an ongoing interaction with target customers with the aim of achieving lasting competitive advantages in the form of brands. Reid et al (2005) describes brand orientation as a model containing six elements associated with organizational attitudes and capabilities named as shared brand vision, shared brand functionality, shared brand positioning, brand return on investment, brand symbolism and brand value-adding 
capability. In addition, Baumgarth (2009) clarifies brand orientation as a precise type of marketing orientation, which is notable by the high significance accorded to branding by top management. It also entails a strongly methodical approach to brand management characterized by an offer that is comparatively steady, consistent and pertinent to the buyer and obviously discriminated from the opposition.

Customer orientation can be explained as a sales approach and customer-relations in which firm focuses on helping consumers to convene their needs for a long-term era. It is the mixtures of actions taken by a company to support its sales and service staffs in considering client needs and satisfaction their major priorities. "A customer orientation approaches that the major task of the organization is to decide the perceptions, needs, and wants of target markets and to satisfy them through the plan, communication, pricing, and delivery of suitable and competitively viable contributions" (Kotler, 1987), and this will be approved as a working description for this study. "Customer orientation and competitor orientation are each defined symmetrically to market orientation, incorporating the components of generation and dissemination of intelligence and action" (Sorensen, 2008). Customer orientation is a business strategy that requires management and employees to hub on the diversified demands of its customers. Customers' needs and wants are always in a changing mode. A skilled workforce and customer oriented company always focuses on how to meet these needs, even it can stimulate new needs through the identification of pros and cons of the current offerings. Being customer-oriented actually means being keen about customers needs and wants, by providing quality goods and services, that meets customers expectations. Customer-oriented firm is engaged in by firms that sell products and services to the general public and require keeping a positive, highly appreciated public image.

Next to be customer-oriented, is the concept of competitor-orientation. "Customer orientation and competitor orientation are each distinct symmetrically to market orientation, incorporating the elements of generation and distribution of aptitude and act" (Sorensen, 2008). A competitivelyoriented firm engages itself in constantly reassessment of its strengths and weaknesses beside its competitors. This performance evaluation is justified for both of the market leader and market followers. This performance evaluation may comprise sectors of production efficiency, pricing strategy, product/service delivery times, customer satisfaction, innovation, and employee retention and market share. In a spirited financial system, each economic entity is attempting to maximize benefits for itself at the cost of its competitors. Deshpandey, Farley, and Webster (1993) explained that, "an unbalanced focus towards the competitors is not desirable since exclusive attention on the competition can lead to the neglect for the difficultly of its customers." Narver and Slater (1990) claimed that "competitor orientation alerts on consideration of the force and weaknesses of accessible and potential competitors as well as on discovering their approach to adapt into improved ideas to meet the customer satisfaction." A competitive firm must recognize the hazy market needs and settle in the market dynamics caused by competitor orientation, hence enhanced firm performance because the objective of competitor centered approach is to stay at the front position of competitors. Competitor orientation approach helps a firm to assign the limited resources competently, in some cases arranging new necessary assets, to offer better customers satisfaction and value towards their products and services; with continuous research and investigating competitive, differentiate and distinguishing.

Saku Hirvonen et. al (2014) determined if brand orientation brand performance relationship is moderated by firm-related inner factors and or market-related outer factors. Six moderators are investigated as (1) firm age, (2) firm size, (3) branding know-how, (4) customer type, (5) industry type and (6) market life cycle. 
International Journal of Managing Value and Supply Chains (IJMVSC) Vol. 7, No. 1, March 2016

\section{RESEARCH OBJECTIVES}

\subsection{HYPOTHESIS DEVELOPMENT}

In the development of brand management firms should strongly monitor the needs and tastes of different stakeholders, create brand values and convey them to different stakeholders (Keller 1998; Kapferer 2001). Thus, for a firm, both philosophies may be regarded as marketing related ways to pursue competitive benefit in the markets and with diverse interest groups. Firm differentiates both the need for market based knowledge and the significance to create added value through branding. In has also been suggested that brand orientation must be standed on the basis of market orientation and that brand orientation is the subsequent step in the chase of competitive advantage (Urde 1999; Wong and Merrilees 2007). We argue that market orientation is an antecedent of brand orientation. As a result, we hypothesize that the three elements of market orientation have positive impact on brand orientation.

\subsubsection{Customer Orientation and Brand Orientation:}

As presented by Van Gelder (2003), brands are models which are shaped by organizations to kindle customer participation and with the hope of persuading a buying actions that is both promising and maintainable to firms. Therefore, a brand that is well-crafted inclines to demand more to consumers, and in turn tends to be more noticeable in the marketplace, thus leading to satisfactory marketing performance results (e.g., customer relationship performance) (Aaker, 1996; Kapferer, 2008). One of the inspiring literary papers on the synergy between brand orientation and market orientation, Urde (1999) apparently states that "to be brand oriented is to be more than market oriented". Correspondingly, some recent experiential studies conjecture that brand orientation raises the brand performance of not just larger companies, but for small and medium-sized businesses (Baumgarth, 2010; Merrilees, Rundle-Thiele and Lye, 2011. In addition, the study of O'Cass and Ngo (2011) offers extra observed evidence that the brand orientation of a service-oriented business is positively related to customer enablement as well as customer satisfaction. Although a few empirical research has been conducted in this field, particularly in the background of small enterprises, we tried to bring into line our thoughts to some of the above-mentioned studies and further suggest that:

\section{H1: Customer orientation has a positive impact on brand orientation}

\subsubsection{Competitor Orientation and Brand Orientation:}

Some researchers (Han et al. 2000, Gray et al. 1998, Narver\& Slater 1990) believe that competitor orientation as a noteworthy fraction of market orientation. Competitor orientation moves toward with an organization-wide concerned of what characteristics have the market where it is operating.

\section{H2: Competitor orientation has a positive impact on brand orientation}

\subsubsection{Inter-Functional Orientation and Brand Orientation:}

A company must be in a position to ask any individual or function to integrate effectively and utilize all its resources to demonstrate if not create value (Narver et al., 1990). This implies that 
organizations need to arrange themselves in a matrix format around the customer. This dimension is addressed for completeness and will not form an integral part of this study. In conclusion, the reason why this study focuses on customer orientation and competitor orientation as dimensions of market orientation is because this study argues that brand-oriented organizations that seek to be competitive in the long-term need to consider their customers and competitors in order to build long lasting and distinctive brands. Here we get our $3^{\text {rd }}$ hypothesis:

\section{H3: Inter-functional coordination has a positive effect on brand orientation}

\subsubsection{Brand Orientation and Brand Performance}

Becoming brand oriented means having a broad acceptance of the implication of branding to the entire organization and its business processes. So, brand oriented marketing should become a mid force in following brand related performance, such as brand awareness, devoted customers, a optimistic image and a first-class reputation. Hence, brand orientation may be seen to hold up the growth of stronger brands and to enhance brand's performance and business performance (Ewing and Napoli 2005). In the previous literature some experimental proof about the association between brand orientation and brand performance has been presented. According to the results of Wong and Merrilees (2008) brand orientation has a direct control on brand performance. Thus, we hypothesize:

H4: Brand orientation a positive impact on brand performance.

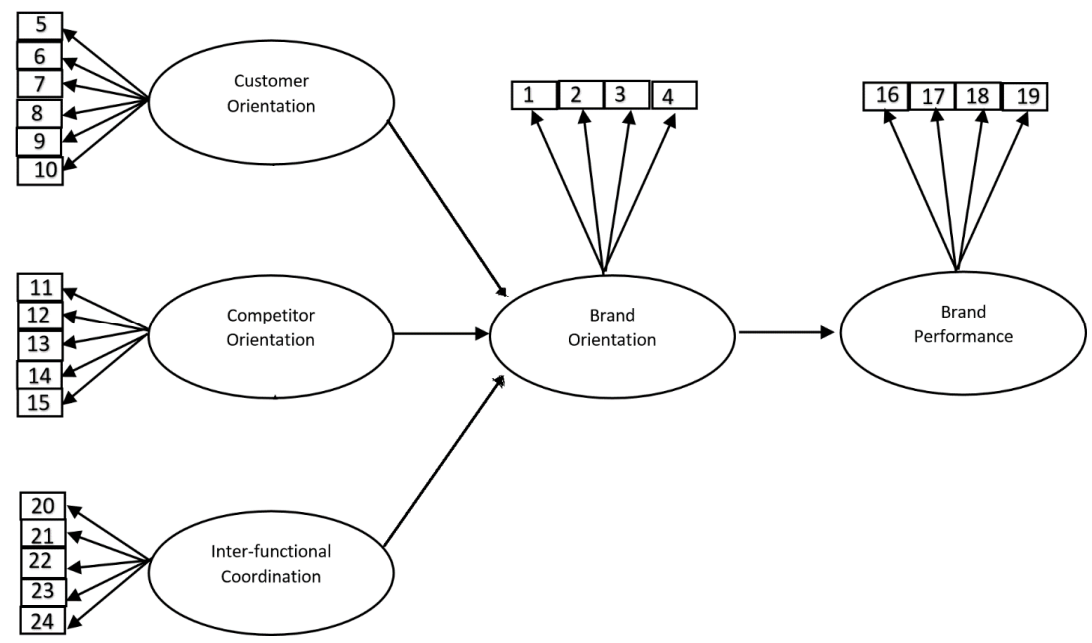

Figure 1: Brand Performance Achievement through Brand Orientation Influenced by Customer Orientation, Competitor Orientation and Inter-Functional Co-ordination

According to the developed hypotheses, the research objectives can be restated as the followings:

- To justify if customer orientation has a positive impact on brand orientation or not

- To justify if competitor orientation has a positive influence on brand orientation or not

- To determine the inter-functional coordination has a positive influence on brand orientation

- To show that brand orientation is positively related to brand performance 


\section{RESEARCH METHODOLOGY}

A survey was conducted among 50 respondents selected from the small apparel store owners in Khulna City. All the responses were received, the response rate being 100 percent. Brand orientation was measured with 4 initial items derived from the earlier literature discussed above and customer orientation was measured with six items. Competitor orientation and interfunctional coordination had 5 items each, while Brand performance had 4 items.

The questionnaire is comprised of 24 items in total. Out of which 4 items are used for measuring brand orientation (V1-V4), 6 items are used for measuring customer orientation (V6-V10), 5 items are used for measuring competitor orientation (V11-V15), 4 items are used for measuring Brand Performance(V16-V19), and last 5 items are used for measuring Inter-Functional Coordination (V20-V24). The Cronbach's Alpha value comes as 0.918 which certifies the satisfactory level of internal consistency reliability.

Here brand orientation is considered as dependent variable, regression analyses have been conducted to judge the relationship with independent variables as customer orientation, competitor orientation and inter-functional co-ordination. Then another regression analysis is conducted by considering brand orientation as independent variable and brand performance as a dependent variable.

Principal component method is used to make an exploratory factor analysis with the varimax rotation was used to verify that the suggested constructs are estranged from each other. No factors were required to be deleted observing the rotated component table.

Table 1: Sampling Adequacy KMO and Bartlett's Test

\begin{tabular}{|ll|c|}
\hline Kaiser-Meyer-Olkin Measure of Sampling Adequacy. & .941 \\
Bartlett's Test of Sphericity & Approx. Chi-Square & $1.701 \mathrm{E} 3$ \\
& $\mathrm{df}$ & 276 \\
& Sig. & .000 \\
\hline
\end{tabular}

The KMO and Bartlett's Test value comes 0.941 which explains a high degree of sampling adequacy and at 276 degree of freedom, this is highly significant.

\section{RESULTS AND DISCUSSION}

\section{Hypothesis 1: Customer orientation has a positive effect on brand orientation}

The statistical calculation using SPSS shows a regression level of .745 between brand orientation (dependent) and customer orientation (independent). The $\mathrm{R}$ square is .556 having a standard error of .712 (approx.). The variables under customer orientation were after sales service is an important part, encouraging customer feedback, measuring customer satisfaction, having strong commitment to customers, looking forward for new ways to create customer value in products and services, and lastly business objectives are driven by customer satisfaction. The regression result of .556 shows that customer orientation has a positive effect on brand orientation. At 6 
degree of freedom, the F value of 8.961 is highly significant. Hence hypothesis 1 is accepted. Brand orientation can account for $55.6 \%$ of competitor orientation. There may be many factors that can explain its variation, our model is eligible to explain $49.4 \%$ of those, it also mean that $71.16 \%$ of variation in brand orientation can be explained by only competitor orientation.

Table 2: Regression between Customer orientation's effects on brand orientation

\begin{tabular}{|l|l|l|l|l|}
\hline Model & $\mathrm{R}$ & R Square & $\begin{array}{l}\text { Adjusted } \\
\text { Square }\end{array}$ & $\begin{array}{l}\text { Std. Error of the } \\
\text { Estimate }\end{array}$ \\
\hline 1 & $.745^{\mathrm{a}}$ & .556 & .494 & .71161170 \\
\hline
\end{tabular}

a. Predictors: (Constant), After-sales services is a significant part of our business strategy, We cheer up customer feedback as it help us do a enhanced job, We assess customer satisfaction on a regular basis, We have a strong promise to our customers, We are always looking for new ways to create customer value in our products and services, Our business objectives are driven by customer satisfaction.

Table 3: ANOVA test between Customer Orientation and Brand Orientation

\begin{tabular}{|c|c|c|c|c|c|c|}
\hline \multicolumn{2}{|c|}{ Model } & $\begin{array}{l}\text { Sum of } \\
\text { Squares }\end{array}$ & df & Mean Square & $\mathrm{F}$ & Sig. \\
\hline \multirow[t]{3}{*}{1} & Regression & 27.225 & 6 & 4.538 & 8.961 & $.000^{\mathrm{a}}$ \\
\hline & Residual & 21.775 & 43 & .506 & & \\
\hline & Total & 49.000 & 49 & & & \\
\hline
\end{tabular}

\section{Hypothesis 2: Competitor orientation has a positive effect on brand orientation}

The statistical calculation using SPSS shows a regression level of .878 between brand orientation (dependent) and competitor orientation (independent). The $\mathrm{R}$ square is .770 having a standard error of .5056 (approx.). The variables under competitor orientation were top managers often discussing competitor's actions, regularly monitoring competitors marketing efforts, responding rapidly to competitor's actions, frequently collecting data about competitors to help support marketing, people being instructed to monitor and report on competitor activity. The regression result of .770 shows that competitor orientation has a positive effect on brand orientation. At 5 degree of freedom, the F value of 29.522 is highly significant. Hence hypothesis 2 is accepted.

Brand orientation can account for $77.0 \%$ of competitor orientation. There may be many factors that can explain its variation, our model is eligible to explain $74.4 \%$ of those, it also mean that $50.57 \%$ of variation in brand orientation can be explained by only competitor orientation. 
International Journal of Managing Value and Supply Chains (IJMVSC) Vol. 7, No. 1, March 2016

Table 4: Regression between Competitor Orientation's effects on Brand Orientation

\begin{tabular}{|l|l|l|l|l|}
\hline Model & $\mathrm{R}$ & R Square & $\begin{array}{l}\text { Adjusted } \\
\text { Square }\end{array}$ & Std. Error of the Estimate \\
\hline 1 & $.878^{\mathrm{a}}$ & .770 & .744 & .50569854 \\
\hline
\end{tabular}

Predictors: (Constant), Our higher managers' frequently converse about competitors' actions, We often check our competitor's marketing strategies, We react rapidly to competitor's actions, We regularly gather data about our competitors to support the marketing department, staffs are instructed to observe and report on competitor activity

Table 5: ANOVA test between Competitor Orientation and Brand Orientation

\begin{tabular}{|ll|l|l|l|l|l|}
\hline Model & & Sum of Squares & df & Mean Square & F & Sig. \\
\hline 1 & Regression & 37.748 & 5 & 7.550 & 29.522 & .000 \\
& Residual & 11.252 & 44 & .256 & & \\
& Total & 49.000 & 49 & & & \\
& & & & & & \\
& &
\end{tabular}

\section{Hypothesis 3: Inter-functional coordination has a positive effect on brand orientation}

The statistical calculation using SPSS shows a regression level of .578 between brand orientation (dependent) and inter-functional coordination (independent). The R square is .335having a standard error of .860 (approx.). The variables under inter-functional coordination were regularity of discussing customer needs, sharing market information inside organization, involvement of persons in charge of different business operation in preparing business plan, regularity of having inter-organization meetings to discuss market trends and developments, and integrating the activities inside the organization. The regression result of .335 shows that inter-functional coordination has a positive effect on brand orientation. At 5 degree of freedom, the $\mathrm{F}$ value of 4.424 is highly significant. Hence hypothesis 3 is accepted.

Table 6: Regression between Inter-functional co-ordinations and Brand Orientation

\begin{tabular}{|l|l|l|l|l|}
\hline Model & $\mathrm{R}$ & R Square & $\begin{array}{l}\text { Adjusted } \\
\text { Square }\end{array}$ & $\mathrm{R}$ \\
\hline 1 & $.578^{\mathrm{a}}$ & .335 & .259 & .86086900 \\
\hline
\end{tabular}

a. Predictors: (Constant), We regularly talk about customer needs, Market information is shared inside the firm, employees in charge of different business operations are concerned in preparing business plans, We frequently have internal meetings to discuss market trends and developments, We integrate the activities inside our organization. 
International Journal of Managing Value and Supply Chains (IJMVSC) Vol. 7, No. 1, March 2016

Table 7: ANOVA test between Inter-functional co-ordinations and Brand Orientation

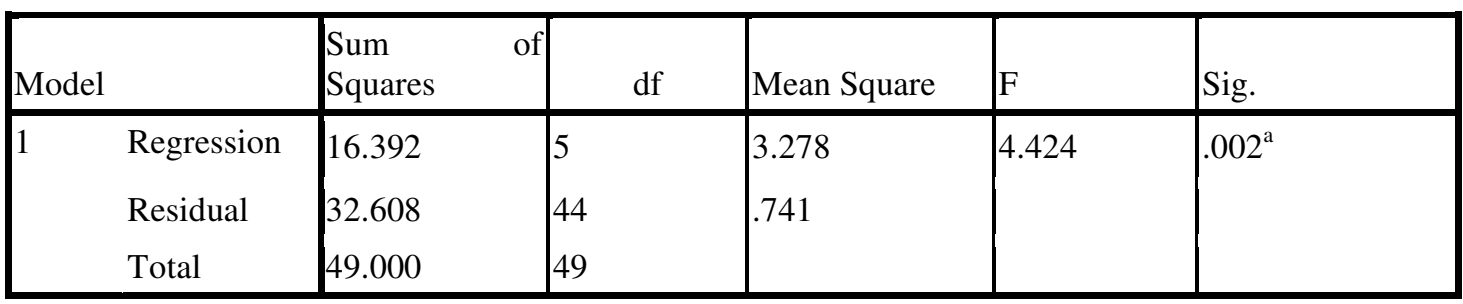

\section{Hypothesis 4: Brand orientation is directly and positively related to brand performance}

The statistical calculation using SPSS shows a regression level of .495 between brand performance (dependent) and brand orientation (independent). The $\mathrm{R}$ square is .245having a standard error of .906 (approx.). The variables under brand orientation were the brand being an important asset, branding flowing through all marketing activities, branding being essential in running the company, and branding being essential to strategy. The regression result of .245 shows that brand orientation has a positive consequence on brand performance. Brand orientation can account for $24.5 \%$ of brand performance. There may be many factors that can explain this variation, our model is eligible to explain $17.8 \%$ of those, it also mean that $90.65 \%$ of variation in the brand performance can be explained by only brand orientation. At 4 degree of freedom, the F value of 3.655 is highly significant. Hence hypothesis 4 is accepted.

Table 8: Regression between Brand Orientation and Brand Performance

\begin{tabular}{|c|c|c|c|c|}
\hline Model & $\mathrm{R}$ & R Square & $\left|\begin{array}{ll}\text { Adjusted } & \mathrm{R} \\
\text { Square } & \end{array}\right|$ & Std. Error of the Estimate \\
\hline 1 & $.495^{\mathrm{a}}$ & 245 & .178 & .90657001 \\
\hline
\end{tabular}

a. Predictors: (Constant), The brand value is the most important asset for us, Branding is reflected through all our marketing activities, Branding is crucial in running this company, Branding is essential to our strategy.

Table 9: ANOVA test between Brand Orientation and Brand

\section{Performance}

\begin{tabular}{|ll|l|l|l|l|l|}
\hline \multicolumn{2}{|l|}{ Model } & Sum of Squares & $\mathrm{df}$ & $\begin{array}{l}\text { Mean } \\
\text { Square }\end{array}$ & $\mathrm{F}$ & Sig. \\
\hline 1 & Regression & 12.016 & 4 & 3.004 & 3.655 & $.012^{\mathrm{a}}$ \\
& Residual & 36.984 & 45 & .822 & & \\
\multicolumn{1}{|l|}{ Total } & 49.000 & 49 & & & \\
\hline
\end{tabular}

The summary table shows the various sums of squares described in Table 9, and the degrees of freedom associated with each. From these two values, the average sums of squares (the mean squares) can be calculated by dividing the sums of squares by the associated degrees of freedom. The most important part of the table is the $F$-ratio and the associated significance value of that $F$ ratio. For these data, $F$ is 3.655, which is not that much significant at $p<.001$ (because the value in the column labelled Sig. is more than .001). This result tells us that there is more than a $0.1 \%$ 
chance that an $F$-ratio this large would happen if the null hypothesis were true. Therefore, we can conclude that our regression model results in significantly better prediction of brand performance if we used the brand orientation.

Table 10: Structural Model Results

\begin{tabular}{|l|l|l|}
\hline Structural Model (H1-H4) & Std est. & Sig. \\
\hline H1: Customer Orientation affecting Brand Orientation & .556 & .000 \\
\hline H2: Competitor Orientation affecting Brand Orientation & .770 & .000 \\
\hline $\begin{array}{l}\text { H3: Inter-Functional Coordination affecting Brand } \\
\text { Orientation }\end{array}$ & .335 & .002 \\
\hline H4: Brand Orientation affecting Brand performance & .245 & .012 \\
\hline
\end{tabular}

The Table 10 summarizes the hypotheses at their relevant significance level. Our first hypothesis, (H1: Customer Orientation affecting Brand Orientation) has a standard error of estimate value of .556 which means $55.6 \%$ of variation in brand orientation can be explained by customer orientation. The second hypothesis, (H2: Competitor Orientation affecting Brand Orientation), has a standard error of estimate value of .770 which means $77.0 \%$ of variation in brand orientation can be explained by competitor orientation. Third hypothesis, (H3: Inter-Functional Coordination affecting Brand Orientation) has a standard error of estimate value of .335 which means $33.5 \%$ of variation in brand orientation can be explained by inter-functional orientation. And finally the last one (H4: Brand Orientation affecting Brand performance) has a standard error of estimate value of .245 which means $24.5 \%$ of variation in brand performance can be explained by brand orientation.

\section{Factor Analysis:}

The following table containing the factor loading data explains the simple correlation between variables and factors.

Table 11: Factor Loading

\begin{tabular}{|l|l|l|l|}
\hline Measure items (Alpha) & $\begin{array}{l}\text { Initial } \\
\text { eigen } \\
\text { value }\end{array}$ & $\begin{array}{l}\text { Variance } \\
\text { explained } \\
(\boldsymbol{\%})\end{array}$ & $\begin{array}{l}\text { Factor } \\
\text { loading }\end{array}$ \\
\hline Brand Orientation & 19.013 & 22.037 & \\
$\begin{array}{l}\text { 1. Branding is essential to our strategy } \\
\text { 2. Branding flows through all our marketing activities } \\
\text { 3. Branding is essential in running this company }\end{array}$ & & & .563 \\
4. The brand is important asset for us & & & .634 \\
\hline $\begin{array}{l}\text { Customer Orientation } \\
\text { 5. We have a strong commitment to our customers }\end{array}$ & 3.056 & 21.719 & .540 \\
\hline $\begin{array}{l}\text { 6. We are always looking for new ways to create customer } \\
\text { value in our products and services }\end{array}$ & & & .555 \\
$\begin{array}{l}\text { 7. We encourage customer feedback because it helps us do a } \\
\text { better job }\end{array}$ & & & .556 \\
$\begin{array}{l}\text { 8. Our business objectives are driven by customer } \\
\text { satisfaction }\end{array}$ & & & .629 \\
\hline
\end{tabular}


International Journal of Managing Value and Supply Chains (IJMVSC) Vol. 7, No. 1, March 2016

\begin{tabular}{|c|c|c|c|}
\hline $\begin{array}{l}\text { 9. We measure customer satisfaction on a regular basis } \\
\text { 10. After-sales services is an important part of our business } \\
\text { strategy }\end{array}$ & & & $\begin{array}{l}.613 \\
.697\end{array}$ \\
\hline \multirow{5}{*}{$\begin{array}{l}\text { Competitor Orientation } \\
\text { 11. We regularly monitor our competitors' marketing efforts } \\
\text { 12. We frequently collect data about our competitors to help } \\
\text { support our marketing } \\
\text { 13. Our people are instructed to monitor and report on } \\
\text { competitor activity } \\
\text { 14. We respond rapidly to competitors' actions } \\
\text { 15. Our top managers often discuss competitors' actions }\end{array}$} & \multirow[t]{5}{*}{2.378} & \multirow[t]{5}{*}{19.163} & \\
\hline & & & .753 \\
\hline & & & .789 \\
\hline & & & .730 \\
\hline & & & $\begin{array}{l}.732 \\
.543\end{array}$ \\
\hline \multirow{3}{*}{$\begin{array}{l}\text { Brand Performance } \\
\text { 16. We have reached desired image in market } \\
\text { 17. Our firm has a strong reputation } \\
\text { 18. Our firm has built a strong customer brand loyalty } \\
\text { 19. Our brand has a strong brand awareness in the market }\end{array}$} & \multirow[t]{3}{*}{2.036} & \multirow[t]{3}{*}{14.856} & \\
\hline & & & .748 \\
\hline & & & .526 \\
\hline \multirow{7}{*}{$\begin{array}{l}\text { Inter-functional Coordination } \\
\text { 20. Market information is shared inside our organization } \\
\text { 21. Persons in charge of different business operations are } \\
\text { involved in preparing business plans/strategies } \\
\text { 22. We do a good job integrating the activities inside our } \\
\text { organization } \\
\text { 23. We regularly have inter-organizational meetings to } \\
\text { discuss market trends and developments } \\
\text { 24. In our firm we regularly discuss customer needs }\end{array}$} & \multirow{7}{*}{1.738} & \multirow{7}{*}{10.652} & .617 \\
\hline & & & .538 \\
\hline & & & .608 \\
\hline & & & .580 \\
\hline & & & \\
\hline & & & .527 \\
\hline & & & \\
\hline
\end{tabular}

The initial factor procedure, with all the 24 items, produced a five-factor solution with eigen values greater than 1 . In order to ensure practical significance, factor loadings less than 0.50 were suppressed (Hair et al., 1998). The final tabulation is consisted of five factors with eigen values greater than 1 representing 79.219 percent of total variance of the variables.

In the following table, the rotated components with initial eigen value, factor loadings and cumulative variance are given as calculated. The total cumulative percentage of variance is 88.427 which indicates acceptable data. 
International Journal of Managing Value and Supply Chains (IJMVSC) Vol. 7, No. 1, March 2016

Table 12: Rotated Variance Calculation

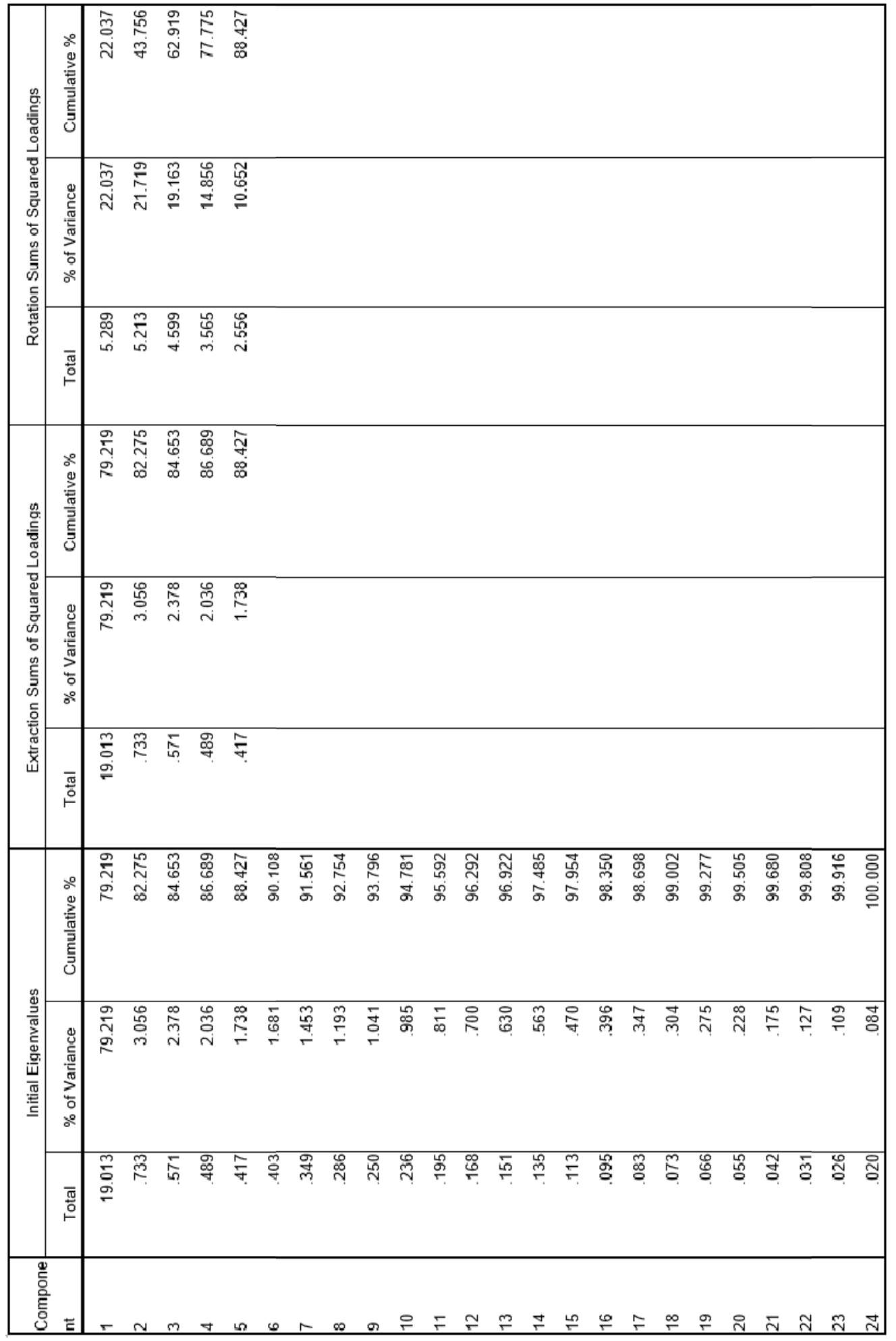


The Table 12, lists the initial eigen values associated with each linear component (factor) before extraction, after extraction and after rotation. Before extraction, SPSS has identified 24 linear components within the data set as there are variables and so there will be as many factors as variables. The eigen values associated with each factor represent the variance explained by that particular linear component and SPSS also displays the eigen value in terms of the percentage of variance explained (so, factor 1 explains $79.219 \%$ of total variance). It should be clear that the first few factors explain relatively large amounts of variance (especially factor 1) whereas subsequent factors explain only small amounts of variance. SPSS then extracts all factors with eigen values greater than 1, which leaves us with four factors. The eigen values associated with these factors are again displayed (and the percentage of variance explained) in the columns labeled as Extraction Sums of Squared Loadings. The values in this part of the table are the same as the values before extraction, except that the values for the discarded factors are ignored (hence, the table is blank after the fifth factor). In the final part of the table (labeled Rotation Sums of Squared Loadings), the eigen values of the factors after rotation are displayed. Rotation has the effect of optimizing the factor structure and one consequence for these data is that the relative importance of the five factors is equalized. Before rotation, factor 1 accounted for considerably more variance than the remaining four $(79.219 \%$ compared to 3.056, 2.378, 2.036 and 1.738\%), but after extraction it accounts for only $22.037 \%$ of variance (compared to $43.756,62.919,77.775$ and $88.427 \%$ respectively).

\section{CONCLUSION}

This paper adds contribution to the marketing literature in two ways: first, it empirically scrutinizes the influence of the three elements of market orientation on brand orientation and second, it brings the context of SMEs into the discussion. The results of this study show that market orientation, brand orientation and brand performance are related to construct customer orientation, followed by inter-functional coordination, has the strongest positive effect on brand orientation which in turn affects positively brand performance. The study results empirically verify the conceptual work that suggests that the customer is the major link between market orientation and brand orientation. On the other hand, our results indicate that competitor orientation has no significant effect on brand orientation. In addition, brand orientation has a considerable consequence on brand performance as was also proved in previous research papers. Our model demonstrates that market orientation precedes brand orientation. Furthermore, our findings show that market orientation and brand orientation are related to better brand performance. According to our results, those SMEs that are more market and brand-oriented have stronger brands than those companies which are not oriented towards markets and brand building. Superior brand performance leads to stronger brand image and reputation, higher brand awareness and increased brand loyalty. So, managers should pay attention to market sensing and brand building activities. They should understand that brands are strategically vital possessions through which companies can attain market-driven competitive advantage. For scope of further study, it can be said that, this model can be used to determine the brand performance in case of other consumer goods like electronic products, IT products, restaurant service, etc.

\section{ACKNOWLEDGEMENTS}

The authors would like to express heartfelt gratitude to a number of persons who have extended their kind cooperation to the successful implementation of the study. Firstly it goes to Professor Dr. Eijaz Ahmed Khan from Business Administration Discipline, Khulna University, for his keen 
International Journal of Managing Value and Supply Chains (IJMVSC) Vol. 7, No. 1, March 2016

supervision and guidance in the formation of the model and data analysis. Secondly, a thankful hand goes to the respondents who considered providing the opportunity to survey on their business. And last but not the least, our friends and family have always been beside us with their supports.

\section{REFERENCES}

1. Aman, H. (2015). "Online branding strategies-modern branding aid for small enterprise (s)."

2. Ahonen, T. T. and A. Moore (2005). "Communities dominate brands." London: Futuretext.

3. Abimbola, T., et al. (2007). "A theory of brand-led small enterprise new venture development." Qualitative Market Research: An International Journal 10(4): 403-415.

4. O'Callaghan, E. (2009). "Internal branding and brand commitment: A quantitative investigation into corporate brand building in a retail store network."

5. Abimbola, T. (2001). "Branding as a competitive strategy for demand management in small enterprises." Journal of research in marketing and entrepreneurship 3(2): 97-106.

6. Keller, Kevin Lane. "Branding perspectives on social marketing." Advances in Consumer Research 25.1 (1998): 299-302.

7. Kapferer, Jean-Noel. The new strategic brand management: Advanced insights and strategic thinking. Kogan page publishers, 2012.

8. Urde, Mats. "Brand orientation: A mindset for building brands into strategic resources." Journal of marketing management 15.1-3 (1999): 117-133.

9. Wong, H., Merrilees, B., 2007. Closing the marketing strategy to performance gap: the role of brand orientation. Journal of Strategic Marketing 15 (5), 387-402.

10. Van Gelder, S. (2004). Global brand strategy. The Journal of Brand Management, 12(1), 39-48.

11. Aaker, David A. Building strong brands. Simon and Schuster, 2012.

12. Kapferer, Jean-Noel. "The new strategic brand management: creating and sustaining brand equity." Les editions d'Organization, London (2008).

13. Urde, Mats. "Brand orientation: A mindset for building brands into strategic resources." Journal of marketing management 15.1-3 (1999): 117-133.

14. Baumgarth, C. (2010). "Living the brand": brand orientation in the business-to-business sector. European Journal of Marketing, 44(5), 653-671.

15. Merrilees, B., Rundle-Thiele, S., \& Lye, A. (2011). Marketing capabilities: Antecedents and implications for B2B SME performance. Industrial Marketing Management, 40(3), 368-375.

16. O'Cass, A., \& Viet Ngo, L. (2011). Achieving customer satisfaction in services firms via branding capability and customer empowerment. Journal of Services Marketing, 25(7), 489-496.

17. Han, Byung Hee, and David M. Holtzman. "BDNF protects the neonatal brain from hypoxicischemic injuryin vivo via the ERK pathway." The Journal of Neuroscience 20.15 (2000): 57755781.

18. Gray, B., Matear, S., Boshoff, C., \& Matheson, P. (1998). Developing a better measure of market orientation. European journal of marketing, 32(9/10), 884-903.

19. Narver, J. C., \& Slater, S. F. (1990). The effect of a market orientation on business profitability. The Journal of Marketing, 20-35.

20. Day, G. S., \& Wensley, R. (1988). Assessing advantage: a framework for diagnosing competitive superiority. The Journal of Marketing, 1-20.

21. Narver, J. C., \& Slater, S. F. (1990). The effect of a market orientation on business profitability. The Journal of Marketing, 20-35.

22. Narver, J. C., \& Slater, S. F. (1990). The effect of a market orientation on business profitability. The Journal of Marketing, 20-35.

23. Napoli, J., Ewing, M. T., \&Berthon, P. (2005). Brand Matters: An Examination of Small to Medium Sized Enterprises. In ANZMAC Conference. December (pp. 65-69).

24. Yin Wong, Ho, and Bill Merrilees. "The performance benefits of being brand-orientated." Journal of Product \& Brand Management 17.6 (2008): 372-383. 
International Journal of Managing Value and Supply Chains (IJMVSC) Vol. 7, No. 1, March 2016

25. Urde, Mats. "Brand orientation: A mindset for building brands into strategic resources." Journal of marketing management 15.1-3 (1999): 117-133.

26. Simoes, Claudia, and Sally Dibb. "Rethinking the brand concept: new brand orientation." Corporate Communications: An International Journal 6.4 (2001): 217-224.

27. Balmer, John MT, and Edmund R. Gray. "Corporate brands: what are they? What of them?." European Journal of Marketing 37.7/8 (2003): 972-997.

28. Wong, Ho Yin, and Bill Merrilees1. "Closing the marketing strategy to performance gap: the role of brand orientation." Journal of Strategic Marketing 15.5 (2007): 387-402.

29. Urde, Mats. "Brand orientation: A mindset for building brands into strategic resources." Journal of marketing management 15.1-3 (1999): 117-133

30. Merrilees, Bill. "Radical brand evolution: a case-based framework." Journal of Advertising Research 45.02 (2005): 201-210.

31. Urde, Mats. "Brand orientation: A mindset for building brands into strategic resources." Journal of marketing management 15.1-3 (1999): 117-133

32. Wong, H., Merrilees, B., 2008. The performance benefits of being brand oriented. Journal of Product and Brand Management 17 (6), 372-383

33. Aaker, David A., and Managing Brand Equity. "Capitalizing on the Value of a Brand Name." New York (1991).

34. Pappu, R., Quester, P.G., Cooksey, R.W., 2005. Consumer-based brand equity: improving the measurement - empirical evidence. Journal of Product and Brand management 14 (3), 143-154.

35. Baldauf, Artur, Karen S. Cravens, and Gudrun Binder. "Performance consequences of brand equity management: evidence from organizations in the value chain." Journal of product \& brand management 12.4 (2003): 220-236.

36. Kim, Hong-bumm, Woo Gon Kim, and Jeong A. An. "The effect of consumer-based brand equity on firms' financial performance." Journal of consumer marketing 20.4 (2003): 335-351.

37. Calderon, Haydee, Amparo Cervera, and Alejandro Molla. "Brand assessment: a key element of marketing strategy." Journal of Product \& Brand Management 6.5 (1997): 293-304.

38. Chaudhuri, Arjun, and Morris B. Holbrook. "The chain of effects from brand trust and brand affect to brand performance: the role of brand loyalty." Journal of marketing 65.2 (2001): 81-93.

39. Wong, Ho Yin, and Bill Merrilees1. "Closing the marketing strategy to performance gap: the role of brand orientation." Journal of Strategic Marketing 15.5 (2007): 387-402.

40. Yin Wong, Ho, and Bill Merrilees. "The performance benefits of being brand-orientated." Journal of Product \& Brand Management 17.6 (2008): 372-383.

41. Aaker, David A., and Erich Joachimsthaler. "Brand leadership: The next level of the brand revolution." New York (2000).

42. Gromark, Johan, and Frans Melin. "The underlying dimensions of brand orientation and its impact on financial performance." Journal of Brand Management 18.6 (2011): 394-410.

43. Urde, Mats. "Brand orientation: A mindset for building brands into strategic resources." Journal of marketing management 15.1-3 (1999): 117-133

44. http://www.palgravejournals.com/bm/journal/v18/n6/fig_tab/bm201052t2.html\#figure-title, accessed on December 3, 2015, 4.30 p.m

45. Baumgarth, Carsten. "Brand orientation of museums: model and empirical results." International Journal of Arts Management (2009): 30-45.

46. Kotler \& Armstrong. "Marketing: An Introduction”, Prentice-Hall, 1987

47. Drehmann, Mathias, Steffen Sorensen, and Marco Stringa. "The integrated impact of credit and interest rate risk on banks: an economic value and capital adequacy perspective." (2008).

48. Drehmann, Mathias, Steffen Sorensen, and Marco Stringa. "The integrated impact of credit and interest rate risk on banks: an economic value and capital adequacy perspective." (2008).

49. Narver, John C., and Stanley F. Slater. "The effect of a market orientation on business profitability." The Journal of Marketing (1990): 20-35.

50. Hirvonen, Saku, and Tommi Laukkanen. "Brand orientation in small firms: an empirical test of the impact on brand performance." Journal of Strategic Marketing 22.1 (2014): 41-58.

51. http://www.bgmea.com.bd/ 
International Journal of Managing Value and Supply Chains (IJMVSC) Vol. 7, No. 1, March 2016

\section{Authors Short Biography}

Fatima Khan Born on 1985 in Khulna, Bangladesh; Working as Lecturer in Finance for Northern University Bangladesh since 2013; Business Graduate from Business Administration Discipline of Khulna University. Major research areas include stock market investment, credit risk grading, accounting system, brand management and customer satisfaction. Love to travel around the world famous places.

Khan Abdullah Adnan Born on 1991 in Khulna. Business Graduate from Business Administration Discipline of Khulna University. Major research areas include value chain and supply chain management, product development, brand management and customer satisfaction. Passion is photography.
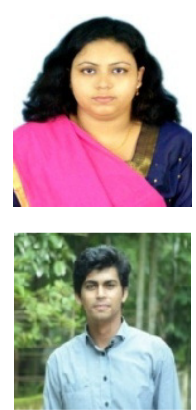